A Violent Peace 
Dof Loren Glass and Kate Marshall, Editors Post•45 Group, Editorial Committee 


\section{A Violent Peace}

Race, U.S. Militarism, and Cultures of Democratization in Cold War Asia and the Pacific

Christine Hong 
STANFORD UNIVERSITY PRESS

Stanford, California

(C)2020 by the Board of Trustees of the Leland Stanford Junior University. All rights reserved.

No part of this book may be reproduced or transmitted in any form or by any means, electronic or mechanical, including photocopying and recording, or in any information storage or retrieval system without the prior written permission of Stanford University Press.

Printed in the United States of America on acid-free, archival-quality paper

Library of Congress Cataloging-in-Publication Data

Names: Hong, Christine, author.

Title: A violent peace : race, U.S. militarism, and cultures of democratization in Cold War Asia and the Pacific / Christine Hong.

Other titles: Post 45.

Description: Stanford : Stanford University Press, 2020. | Series: Post $^{\star} 45$ |

Includes bibliographical references and index.

Identifiers: LCCN 2019048061 (print) | LCCN 2019048062 (ebook) |

ISBN 9781503603134 (cloth) | ISBN 9781503612914 (paperback) |

ISBN 9781503612921 (ebook)

Subjects: LCSH: War and literature-History-2oth century. | Politics and literature-

History-2oth century. | Racism-United States-History-2oth century. | Militarism-

United States-History-2oth century. | Anti-imperialist movements-History-

2oth century. | United States-Armed Forces-East Asia-History. | United States-

Armed Forces-Southeast Asia-History. | United States-Race relations-

Political aspects-History. | United States-Politics and government-1945-1989.

Classification: LCC PN56.W3 H64 2020 (print) | LCC PN56.W3 (ebook) |

DDC 809/.93358-dc23

LC record available at https://lccn.loc.gov/2019048061

LC ebook record available at https://lccn.loc.gov/2019048062

Cover art: "We Are Here to Stop You," Nan Young Lee, 2013

Cover design: Rob Ehle

Typeset by Kevin Barrett Kane in 10/15 Minion Pro 
to 별 
This page intentionally left blank 